\title{
Onderzoek in de huisartspraktijk: uitdagend en alledaags
}

Citation for published version (APA):

Dinant, G. J. (1999). Onderzoek in de huisartspraktijk: uitdagend en alledaags. Universiteit Maastricht. https://doi.org/10.26481/spe.19990312gd

Document status and date:

Published: 12/03/1999

DOI:

10.26481/spe.19990312gd

Document Version:

Publisher's PDF, also known as Version of record

\section{Please check the document version of this publication:}

- A submitted manuscript is the version of the article upon submission and before peer-review. There can be important differences between the submitted version and the official published version of record.

People interested in the research are advised to contact the author for the final version of the publication, or visit the DOI to the publisher's website.

- The final author version and the galley proof are versions of the publication after peer review.

- The final published version features the final layout of the paper including the volume, issue and page numbers.

Link to publication

\footnotetext{
General rights rights.

- You may freely distribute the URL identifying the publication in the public portal. please follow below link for the End User Agreement:

www.umlib.nl/taverne-license

Take down policy

If you believe that this document breaches copyright please contact us at:

repository@maastrichtuniversity.nl

providing details and we will investigate your claim.
}

Copyright and moral rights for the publications made accessible in the public portal are retained by the authors and/or other copyright owners and it is a condition of accessing publications that users recognise and abide by the legal requirements associated with these

- Users may download and print one copy of any publication from the public portal for the purpose of private study or research.

- You may not further distribute the material or use it for any profit-making activity or commercial gain

If the publication is distributed under the terms of Article $25 \mathrm{fa}$ of the Dutch Copyright Act, indicated by the "Taverne" license above, 


\title{
Onderzoek in de huisartspraktijk: uitdagend en alledaags
}

\begin{abstract}
Rede
uitgesproken bij de aanvaarding van het ambt van bijzonder hoogleraar "Clinical Research in General Practice" aan de Universiteit Maastricht
\end{abstract}

Dr. G.J. Dinant

12 maart 1999 

Mijnheer de Rector, overige leden van het College van Bestuur, leden van de Faculteits Besturen van de Faculteiten Geneeskunde en

Gezondheidswetenschappen, leden van de Raad van Bestuur van thet academisch ziekenhuis Maastricht, collega's, dames en heren,

Zonder enige aarzeling kan ik stellen dat ieder van u in deze zaal aanwezig wel eens met een huisarts heeft gesproken. Dan wel bezocht u zijn (ik gebruik hierna steeds het mannelijke voornaamwoord, ook wanneer het onderwerp vrouwelijk is) spreekuur of bezocht de huisarts $u$ aan huis, dan wel betrof het een intercollegiaal of ander soort overleg. Niettemin is het voor sommigen onder u mogelijk dat zij vandaag voor de eerste keer een huisarts horen 'oreren'. Het is voor mij een eer en genoegen om $u$ allen vandaag te mogen toespreken.

Deze korte beschrijving illustreert waar ik het graag met u over wil hebben; namelijk de diversiteit binnen het vak huisartsgeneeskunde en de rol die weten. schappelijk onderzoek daar in speelt. Daarbij heb ik niet gekozen voor een meer abstracte beschouwing in de "derde persoon', maar voor een uiteenzetting van het aandachtsgebied aan de hand van eigen werk in verleden, heden en toekomst. Echter, voor de plaats bepaling van dit werk is het goed om eerst te kijken naar de geschiedenis van huisartsgeneeskundig onderzoek in Nederland. In die geschiedenis kunnen een aantal periodes worden onderscheiden.

Rond de jaren vijftig werd het medisch onderzoek vrijwel geheel beheerst door medisch-technische specialismen. In die jaren begint de voor de huisartsgeneeskunde belangrijke gedragswetenschappelijke inhaalmanoeuvre, die doorloopt tot in de zestiger jaren. De zestiger en zeventiger jaren kenmerken zich door de opkomst van de grote huisartsgeneeskundige morbiditeitsregistraties. Deze registraties worden gebruikt ter exploratie van het eigen werkterrein, waarvan de morbiditeitstellers en populatie-noemers tot dan toe nauwelijks beschreven waren. De beschrijuingen sluiten goed aan bij het werkveld van de huisarts dat zich kenmerkt door een volledig spectrum van morbiditeit en aandoeningen die het dagelijks leven beïnvloeden en beïnvloed worden door de sociale en gezinsomstandigheden van de patiënt. De ontwikkeling van het klinisch-epidemiologisch en klinisch onderzoek in de huisartsgeneeskunde ten behoeve van de wetenschappelijke onderbouwing, en de verdere ontwikkeling van het huisartsgeneeskundige ambacht volgt in de jaren tachtig en negentig. Kenmerkend is dat alle klachten in ieder stadium door iedereen kunnen worden aangeboden aan de huisarts. Daarbij gaat het veelal om vroege stadia van ziekten, hetgeen het belang van een preventieve attitude van de huisarts onderstreept. Daarnaast zijn continuiteit van zorg, persoonsgerichte zorg en de centrale rol van de huis. arts als 'poortwachter' naar de tweede lijn (en het daaruit voortgekomen transmurale wetemschappelijk onderzoek) vanaf die tijd kenmerkend voor het vak. Parallel hieraan loopt, vanaf het einde van de jaren tachtig, het onderzoek naar 
de kwaliteit van de huisartsgeneeskundige zorg en van de zorgprocessen in de eerstellign en op het grensvlak van eerste en tweede lijn.

Bovenstaande klinkt wellicht indrukwekkend, maar wetenschappelijk onderzoek is niet iets dat u direct herkent wanneer u met een klacht in de spreekkamer van de huisarts zit. Immers, op dat moment heeft u gewoon ergens last van (bijvoorbeeld pijn, moeheid, bloedverlies of hoesten) en stelt u prijs op een diagnose, een geruststelling of een advies. Het lijkt zo eenvoudig maar het is juist dit type alledaagse klachten dat het de huisarts moeilijk kan maken. Zo is het goed mogelijk dat de genoemde klachten signalen zijn van een onschuldige ziekte of aandoening. Bijvoorbeeld de pijn onder in uw rug is gewoon spierpijn, de moeheid komt door een conflict met de werkgever, het bloedverlies duidt op het begin wan de overgang en het hoesten komt door een onschuldige verkoudheid. Echter, dezelfde klachten kunnen voorbodes zijn van ernstige ziekten, zoals gewrichtsrheuma, een hartinfarct, baarmoederhalskanker, of een longontsteking. Niet alleen spelen deze gedachten in het hoofd van de huisarts, ook de patiënt maakt zich regelmatig en soms ook terecht ongerust. ledere huisarts hoort bijna dagelijks dat 'mijn oom ook zo lang liep met moeheid voordat hij plotseling overleed aan een hartinfarct' en dat 'mijn vader maandenlang heeft gehoest voordat werd ontdekt dat hij longkanker had en toen was het te laat".

Een goed opgeleide en ervaren huisarts weet gelukkig hoe hij moet omgaan met deze twijfels en in verreweg de meeste gevallen komt hij snel tot een juiste conclusie en volgt een adequate uitleg aan de patiënt. Maar regelmatig is ook de huisarts in dubio en weet hij niet goed wat de beste aanpak is: dan wel gewoon afwachten, of misschien toch maar een röntgenfoto maken? En voorts, indien de röntgenfoto geen afwijking laat zien, is er dan echt niets ernstigs aan de hand, of moet er toch nog verder worden gekeken? En dan, indien er verder gekeken moet worden, is dat iets voor de ziekenhuisspecialist of is het beter om eerst zelf nog eens goed het bloed te onderzoeken? Het vinden van een antwoord op deze vragen wordt nog moeilijker zodra de huisarts zich realiseert dat het verstandig is om een patiënt niet onnodig ongerust te maken, terwijl hij tegelijkertijd niet lets ernstigs wil missen. Het laatste kan resulteren in een defensieve aanpak door huisartsen, dat wil zeggen het voor de zekerheid de patiënt meer onderzoek aandoen dan strikt noodzakelijk is.

Het woord noodzakelijk suggereert dat er ten aanzien van de voorbeelden die ik zojuist gaf een soort standaard benadering bestaat. Maar helaas, niets is minder waar. De Standaarden (richtlijnen) van het Nederlands Huisartsen Genootschap ten spijt, heb ilk tot op de dag van vandaag nog geen tekst gevonden waarin staat hoe moe iemand moet zijn alvorens de kans reëel wordt dat een hartinfarct dreigt, of hoe lang een patiënt moet hoesten voordat het verstandig wordt om een longfoto te laten maken. 
Maar opnieuw, ook hier weten huisartsen in de dagelijkse praktijk vaak wel raad mee. Zo wordt een diagnose nooit gesteld op basis van eén symptoom of klacht, maar altijd op basis van een verzameling aan gegevens die wordt verkregen door een reeks vragen te stellen aan de patiënt en hem goed te onderzoeken. Maar ook dan ligt de oplossing nog niet altijd in het verschiet. De moeheid gaat bijwoorbeeld niet gepaard met pijn op de borst en heeft dus waarsichijnlijk niet te maken met het hart, maar de patient ziet er toch wel erg belabberd uit en heeft misschien wel een chronische infectie elders in het lichaam.

Samenvattend, goede raad is soms (letterlijk en figuurlijk) duur en het ware een grote sprong voorwaarts als huisartsen konden beschikken over middelen die hem helpen om snel uit de hierbowen geschetste diagnostische dilemma's te komen. Deze hulpmiddelen (of liever 'diagnostische instrumenten") kunnen bestaan uit (combinaties van) korte vragenlijstjes gericht op sleutelsymptomen, onderdelen van het lichamelijk onderzoek en eenvoudig, deels in de eigen praktijk uitvoerbaar onderzoek van bloed en urine. Anders gezegd, het gaat om instrumenten die de huisarts snel, adequaat en liefst ook in een vroeg stadium van een ziekte de weg wijzen in de geschetste 'pluis - niet pluis' dilemma's, met zijn ogen, oren en handen als voornaamste 'gereedschap'.

Voor een deel zijn deze instrumenten al ontwikkeld en onderzocht op hun waarde in de dagelijkse huisartspraktijk. Zo is ieder van u wel bekend met de bepaling van de bloedbezinkingssnelheid, door veel patiënten heel beeldend omgedoopt in 'het bloedbezinksel'. Bekend is dat een verhoogde bloedbezinking kan wijzen op de aanwezigheid van een infectie of een kwaad aardige ziekte. Echter, voor veel huisartsen geldt nog steeds dat 'een afwijkende bloedbezinking alleen nog niets zegt' en dat het dus weinig zin heeft om dit bloedonderzoek uit te voeren. Uit eigen onderzoek bleek dat indien de normaalwaarden van de bepaling ongeveer twee keer zo hoog worden gelegd als door de laboratoria wordt geadviseerd, een afwijkende bloed bezinking alleen al met een kans van bijna $50 \%$ de aanwezigheid van een ernstige infectie of een kwaadaardige ziekte aantoont, onafhankelijk van de leeftijd en het geslacht van de patiënt (althans bij patiënten bij wie de huisarts het verstandig vindt om de bepaling te verrichten $). U$ kunt zich voorstellen dat deze kans verder stijgt wanneer een of twee andere verdachte symptomen (bijvoorbeeld gewichtsverlies en een verandering van de stoelgang) aanwezig zijn.

Graag geef ik nog enkele voorbeelden van snelle 'pluis - niet pluis' diagnostiek, komende uit andere studies waar ik in de afgelopen jaren intensief bij betrokken was. Zo bleek dat bij patiënten die influenza ('griep') hebben en niet langer dan drie dagen ziek zijn, de kans op de gelijktijdige aanwezigheid van iets anders dan griep (bijwoorbeeld een longontsteking) bijna is uitgesloten. Dezelfde studie liet zien dat zodra een patiënt zich bij de huisarts, meldt met het vermoeden griep te 
hebben, een bevestigend antwoord op niet meer dan drie vragen, namelijk 'zijn de klachten acuut begonnen?', 'moet u hoesten?' en 'heeft u koorts?', de kans op de aanwezigheid van influenza vier keer vergroot. Deze kans neemt vanzelfsprekend nog eens flink toe indien er op dat moment toevallig griep heerst.

Een recenter, deels nog lopend onderzoek liet zien dat bij een vrouw die tussen de 50 en 60 jaar oud is, de overgangsjaren achter de rug heeft, er mollig uit ziet en de laatste vijf jaren geen botbreuken opliep, het absolute risico op het aanwezig zijn van osteoporose ("botontkalking) niet meer dan $9 \%$ is (bij een gemiddelde botdichtheid wan $0,740 \mathrm{~g} / \mathrm{cm} 2$ voor deze groep), en dat er dus geen reden is om deze vrouw te adviseren meer melk te gaan drinken, kalktabletten te gaan slikken of naar het ziekenhuis te gaan om een foto van de botten te laten maken. Omgekeerd kwam uit hetzelfde onderzoek naar voren dat bij een vrouw die de 60 is gepasseerd, mager is en korter dan vijf jaar geleden haar pols (of iets anders) brak, het absolute risico op de aanwezigheid van osteoporose stijgt naar $51 \%$ (bij een gemiddelde botdichtheid van $0,721 \mathrm{~g} / \mathrm{cm} 2$ voor deze groep), terwijl de kans dat bij deze patiënte haar botten al in de gevarenzone terecht zijn gekomen (osteopenie) reeds $85 \%$ bedraagt (bij een gemiddelde botdichtheid van $0,775 \mathrm{~g} / \mathrm{cm} 2$ voor deze groep). In dit laatste geval is het evident dat de huisarts een onderzoek van de botten en het voorschrijven van botversterkende medicijnen overweegt en ook dat hij hiermee niet wacht op het moment dat de patient er naar vraagt of iets breekt.

Het is u wellicht opgevallen dat de huisarts ook in dit voorbeeld in eerste instantie aan niet meer dan drie gegevens genoeg heeft om tot een conclusie te komen, namelijk de leeftijd van patiente, haar gewicht in relatie tot haar lengte en het antwoord op de vraag of zij de laatste vijf jaren een botbreuk opliep.

Uit deze voorbeelden mag duidelijk zijn wat de titel van mijn leeropdracht inhoudt. 'Clinical research' betekent niet 'onderzoek in het ziekenhuis', maar wetenschappelijk onderzoek bij en ten behoeve van mensen met bepaalde klachten of verschijnselen, die al dan niet een bepaialde ziekte kunnen hebben. 'General practice' betekent dat het bedoelde onderzoek veelal in de huisartspraktijk en dus buiten het ziekenhuis plaats vindt, in goede samenwerking met collega's die als vakspecialisten in die ziekenhuizen werkzaam zijn. De gegeven voorbeelden laten tevens zien dat het gaat om onderzoek waarvan de resultaten direct toepasbaar zijn in de alledaagse praktijk van de huisarts, dat wil zeggen zonder dat de spreekuren aanzienlijk langer gaan duren, zonder dat de patiënt minder aangenaam aanvullend onderzoek moet ondergaan en tenslotte zonder de patiënt onnodig ongerust te maken of ten onrechte gerust te stellen. In het continueren en initiëren van onderzoek dat tegemoet komt aan deze criteria ligt voor alle huisartsen in Nederland, en met hen voor mij, een grote uitdaging voor de komende jaren. 
Het bedoelde onderzoek sluit impliciet aan bij de toenemende vraag om evidence based handelen van (huis)artsen, dat wil zeggen handelen dat is gebaseerd op wetenschappelijk bewezen (klinische en zo mogelijk ook kosten-) effectiviteit Daarbij dient u evidence niet te zien als een eenduidig "keurmerk", maar als verschillende niveaus van bewijskracht. Overigens is ook dit 'keuren' van wetenschappelijk onderzoek geen eenvoudig proces. Zo is wooral de methodologie van diagnostisch onderzoek nog jong en in ontwikkeling, en derhalve soms moeilijk op haar kwaliteit in te beoordelen. Al in 1988 gaf Knottnerus aan dat de selectie van geschikte onderwerpen en patiënten, en het vinden van de adequate 'gouden standaard' voor een diagnose bij wetenschappelijk onderzoek in de huis.arts. geneeskunde regelmatig moeilijk oplosbare problemen oplevert. Inmiddels kunnen daar nieuwe uitdagingen aan worden toegevoegd, zoals de randomisatie op het niveau van patiënt, praktijk en huisartsengroep, de blindering van interven. ties en de multivariate analyse van onderling samenhangende gegevens. Voorts is het een uitdaging om de uitkomsten van het eenmaal uitgevoerde onderzoek te verwerken in praktische adviezen voor de dagelijkse huisartspraktijk. Adviezen die tevens rekening houden met de voor iedere huisarts zo herkenbare gevoelens van onzekerheid, angst om iets te missen en irritatie over de manier waarop een patiënt zich soms opstelt.

Het proces dat ik hierboven in een paar zinnen beschreef kan deels worden samengevat als het diagnostische gedeelte van 'medische besliskunde'. Niet voor niets hoort u mij tot nu toe nauwelijks over het therapeutische gedeelte van besliskunde spreken. Immers, de werkelijkheid van de alledaagse huisartspraktijk laat zien dat patiënten vooraleerst prijs stellen op een adequate uitleg van wat zij mankeren, en terecht niet graag bereid zijn om bijvoorbeeld medicijnen te gebruiken voor een klacht die de huilsarts niet kan verklaren of begrijpen, of omgekeerd voor iets dat hij als patiënt (nog) niet voelt. In de studies die de afgelopen jaren van start gingen en die ik de komende jaren verder hoop te begeleiden komt dit spectrum van onbegrepen tot onopgemerkt meer expliciet naar voren. Graag vertel ik u daar iets meer over.

Osteoporose is een actueel voorbeeld van iets dat je als patiënt normaal gespro. ken niet voelt, maar je na enige tijd letterlijk en figuurlijk lellijk kan opbreken. Uit ons onderzoek toe nu toe kwam naar woren dat bijna een kwart van alle niet. zieke, niet meer menstruerende vrouwen ouder dan 50 jaar bewezen osteoporose heeft. Deze vrouwen lopen een sterk verhoogde kans om de komende jaren iets te breken, overigens niet alleen door het 'bros' worden van de botten, maar ook omdat men op oudere leeftijd vaak slechter ter been is en sneller valt. Het gevolg van bijvoorbeeld een gebroken heup is niet gering: patiënt ontkomt in elk geval niet aan een ziekenhuisopname, operatie en revalidatie. Maar voor veel ouderen komt daar nog een periode in een verpleegkliniek bij en ligt galandeweg het hele proces voortdurend het gevaar op (deels gevaarlijke) infecties (bijvoor- 
beeld een longontsteking) op de loer. En ook dalarmee is de kous niet af. Zodra patient weer naar huis mag, staat hij vaak alleen voor de zo vanzelfsprekende dagelijkse dingen, zoals boodschappen doen, afwassen, e.d. De angst om weer te vallen kan op dat moment zo groot zijn dat patient ertoe neigt om er, letterlijk, maar liever bij te gaan zitten. Het resultaat daarvan bestaat niet alleen uit een dreigend sociaal isolement, maar ook uit lichamelijk klachten die het gevolg zijn van de afgenomen mobiliteit. U kunt zich voorstellen dat de huisarts vanaf dat moment voor de bijna onmogelijke taak staat om dit proces te keren.

Voorkomen is hier dus duidelijk beter dan niet genezen. Toch voelen veel huisartsen zich vooralsnog niet woldoende vertrouwd met het onderwerp en zijn zij derhalve minder geneigd om te overwegen dat een patiënt wellicht osteoporotisch is. Samenvattend geldt hier dat onopgemerkt ook onbegrepen maakt. Op grond van het lopende onderzoek hopen we over enige tijd te kunnen aangeven bij welke wrouwen in het bijzonder de huisarts bedacht moet zijn op het osteoporotisch worden van de botten, c.q. bij welke vrouwen het verstandig is om daar als huisarts op te anticiperen door tijdig relevante adviezen te geven. In de betreffende studie wordt, door onderzoek van de chromosomen, tevens nagegaan in welke mate erfelijkheid een rol speelt bij dat proces.

De osteoporose-studie is ook een goed voorbeeld vam een multidisciplinair pro-

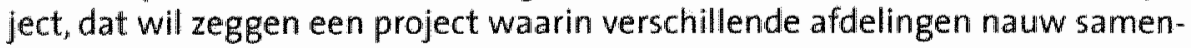
werken, in ons geval huisartsgeneeskunde, interne geneeskunde, nucleaire geneeskunde, klinische genetica, klinische chemie en epidemiologie.

Tegenover een concreet probleem als patiënten met (dreigende) botbreuken staan mensen die zich bij de huisarts presenteren met klachten die ook na een grondige ondervraging (anamnese) en een gedegen lichamelijk anderzoek, en rekening houdend met psychosocialle factoren, onbegrepen of 'vaag' blijven. Gelukkig lost de tijd deze diagnostische problemen vaak op. Immers, veel onbegrepen klachten gaan over zonder dat bijvoorbeeld aanvullend onderzoek nodig was. Echter, andere kumnen leiden tot een cascade wan aanvullend onderzoek (bloed, urine en röntgenfoto's) en verwijzingen. Het ultieme gevolg is een vicieuze cirkel van klachten die in de perceptie van de patiènt niet over kúnnen zijn omdat er immers niet voor niets nog steeds door de dokter naar wordt gekeken, terwijl het doen van aanvullend onderzoek de patiënt ongerust maakt en het telkens weer voelen van de betreffende pijn of moeheid blijft uitlokken. Wij prijzen ons dan ook gelukkig met de steun die we recent kregen van de Ziekenfondsraad, om te onderzoeken bij welke signalen nu precies, in het geval van een onbegrepen klacht, de huisarts op de punt van zijn stoel moet gaan zitten, dan wel wanneer een meer terughoudend beleid verantwoord is. Concreet gaat het om de vraag wanneer en in hoeverre het uitstellen of niet uitvoeren van bloedonderzoek bij patiënten die zich met een onbegrepen of vage klacht bij 
de huisarts presenteren verantwoord is en resulteert in minder kosten voor de gezondheidszorg (1) en om de vraag welke combinaties van symptomen en bevindingen bij een patiënt met een onbegrepen of vage klacht het ontstaan van een ernstige aandoening op termijn kunnen voorspellen (2). Samenvattend geldt voor de huisarts ten aanzien van onbegrepen klachten op dit moment het omgekeerde van dat bij osteoporose: onbegrepen maakt onopgemerkt.

Waar het osteoporose-onderzoek een voorbeeld was van een interdisciplinaire studie binnen het onderzoeksinstituut van éen universiteit (het Research Institute of Extramural and Transmural Health Care van de Universiteit Maastricht [ExTra]), mag het onderzoek naar onbegrepen klachten een illustratie zijn van een nauwe samenwerking met andere universiteiten, in dit geval de Vrije Universiteit en de Universiteit van Amsterdam. Het laatste project is een goed voorbeeld van samenwerking binnen een onderzoeksschool, de Netherlands School of Primary Care Research (CaRe).

Beide studies (ik bedoel "osteoporose" en 'onbegrepen klachten') zijn tevens voorbeelden van de grote omvang die huisartsgeneeskundig onderzoek al snel aanneemt. Zo zijn letterlijk duizenden patiënten en ongeveer 50 huisartspraktijken alleen al in Limburg en Noord-Brabant nodig om de vraagstellingen te kunnen beantwoorden. Daarnaast is de medewerking van nog eens vijf (streek/ziekenhuis) laboratoria in dezelfde regio's gewenst. Het laat zich raden hoeveel inspanning en moed nodig is om dit alles voor te bereiden en gaande te houden, al was het maar omdat iedere huisartspraktijk en elk laboratorium meerdere malen moet worden bezocht. Daar staat tegenover dat de afdeling Huisartsgeneeskunde van onze universiteit en het onderzoeksinstituut ExTra een grote ervaring hebben opgebouwd met (zeer) grootschallige patiëntgebonden studies. Al met al ook voldoende reden waarom op dit moment de praktische aspecten van onderzoek in de huisartspraktijk worden geïnventariseerd en verwerkt in een rapport, dat als lesmateriaal en handleiding kan dienen voor onderzoekers-in-opleiding.

Als woorbeeld van een onderzoek dat zich op het middenveld van het spectrum tussen onbegrepen en onopgemerkt afspeelt noem ik graag de lopende studie naar de diagnostiek en behandeling van lage luchtweginfecties, zoals bronchitis en longontsteking. Het project wordt uitgevoerd in nauwe samenwerking met de afdelingen medische microbiologie en epidemiologie van onze universiteit. Het gaat in dit onderzoek niet om het detecteren van lets dat de patiënt nog. niet voelt of merkt, en ook niet om het analyseren van een onbegrepen klacht, maar om het achterhalen van precies die klachten en bevindingen bij lichamelijk onderzoek die het relevant maken om de patiënt die flink hoest te behandelen met een antibioticum, zoals penicilline, dan wel dit juist niet te doen. 
Waar het in de vorige studies ging om grootschalig, interdisciplinair en interuniversitair onderzoek, is het project "lage luchtweginfecties" een voorbeeld van een onderzoek waarin relatief veel gevraagd wordt van patiënt en huisarts. Een patiènt die in aanmerking komt voor opname in de studie ondergaat in de eerste ronde alleen al een anamnese, een lichamelijk onderzoek, een temperatuurmeting, een uitstrijk van neus en keel en een bloedafname. Voorts wordt hij gevraagd om urine in te leveren, slijm op te vangen en een longfoto te laten maken in het ziekenhuis. $U$ begrijpt dat de patiênt na dit alles het gevoel kan hebben nog nooit zo goed te zijn onderzocht. Echter, de huisarts moet wel even slikken alvorens hij aan deze exercitie begint en zijn praktijkassistente vraagt om deze ins panningen tijdens een regulier spreekuur te leveren. Waar in de eerder genoemde studies de logistiek van het grootschalige onderzoek een centrale plaats inneemt, gaat het in deze laatste studie vooral om het gemotiveerd houden van de deelnemende huisartsen en, niet te vergeten, als onderzoeker zelf gemotiveerd blijven.

In genoemde studies (bloedbezinking, influenza, osteoporose, onbegrepen klachten en lage luchtweginfecties) gaat het letterlijk en figuurlijk om alledlaagse klachten en aandoeningen. Zo zien huisartsen naar schatting gemiddeld 3 vrouwen per week waarvan hij niet weet dat zij osteoporotisch zijn, per dag één tot twee patiënten met onbegrepen klachten en, zeker in deze tijd van het jaar, meerdere malen per dag patiënten die flink hoesten. De studies illustreren ook hoe breed het vak huisartsgeneeskunde is en hoe lastig het kan zijn om de onderwerpen onder te brengen in de iedere dokter bekende orgaanstelsels (tractus), zoals het hartvaatstelsel, of het maagdarmstelsel. Zo kan geen mens zeggen in welk orgaansysteem je bijvoorbeeld moeheid voelt. Ook is het voor huisartsen bijna vanzelfsprekend dat een klacht niet alleen komt, vooral niet bij ouderen. En voorts dat sommige ziekten uit verschillende tractus samengaan, terwijl andere combinaties bijna niet voorkomen. Een interessant voorbeeld van dit laatste is de relatief geringe kans op het vóórkomen van osteoporose bij patiënten met een hartvaartziekte. Reden kan zijn dat patiënten met een hartvaatziekte vaak lange tijd bepaalde diuretica ('plaspillen') gebruiken, waarvan bekend is dat zij beschermen tegen botverlies. Samenvattend is een brede visie op en inzicht in de praktijk van alledag een belangrijke basis voor het doen van huisartsgeneeskundig relevant onderzoek.

Niet alleen een brede visie maar ook een breed front aan onderzoekers is nadig voor het doen van bedoeld onderzoek. Dit varieert van zeer ervaren en soms bijna gepensioneerde huisartsen, via huisartsen in opleiding, tot basisartsen (veelal Assistenten In Opleiding [AIO's]) en student-onderzoekers. Gezien de toelichting hierboven is het logisch dat deze onderzoekers (actief) betrokken zijn bij, dan wel bekend zijn met patiëntenzorg in de huisartspraktijk. 
De consequentie hiervan is echter niet gering. Zo is het voor de ervaren huisarts bepaald geen sinecure om naast zijn drukke praktijkwerk ook wetenschappelijk actief te zijn. Het betekent veelal dat deze collega een nieuw vak moet leren en gedurende jaren een deel van zijn vrije tijd gaat inleveren. Er staat tegenover deze inspanning veelal geen vergoeding die adequate vervanging in de praktijk mogelijk maakt. Het zou een groot goed zijn als in deze situatie zo snel mogelijk verandering komt. Tot die tijd gaat een potentieel aan goede en gemotiveerde (aankomende) huisarts-onderzoekers aan ons voorbij en blijven wetenschappelijke uitdagingen liggen.

Maar gelukkig zijn er ook veelbelovende ontwikkelingen gaande. Zo is de recent tot stand gekomen gecombineerde opleiding tot huisarts en onderzoeker straks wellicht een goed voorbeeld van het Hollandse gezegde 'Jong geleerd is oud gedaan'. De betreffende artsen, AlOTHO's (Assistent In Opleiding Tot Huisarts en Onderzoeker) geheten, opteren voor een opleidingstraject van ongeveer 6 jaar, resulterend in een proefschrift en het 'vakdiploma' huisarts. Naar verwachting zyjn deze huisarts-onderzoekers straks als geen ander in staat om onderzoek door en voor collega-huisartsen te initiëren en te begeleiden. Daarnaast voorzien zij in de behoefte aan huisartsen die in staat zijn om de 'evidence' die met het doen van wetenschappelijk onderzoek wordt verkregen te vertalen in de 'practice'van alledag, bijvoorbeeld door actief te zijn in nascholingscircuits.

Met de selectie van inmiddels tien (beoogde) AlOTHO's is door de Maastrichtse vakgraep Huisartsgeneeskunde en het onderzoeksinstituut ExTra dan ook een cruciale, maar niet gemakkelijke weg ingeslagen. Immers, AlOTHO's gaan een lang en zwaar traject tegemoet. Van hen wordt ook verwacht dat zij niet bang zijn om een beetje te avonturieren, een weg te vinden in praktijk en onderzoek tegelijkertijd, te struikelen over onverwachte obstakels, weer op te staan en opnieuw vooruit te kijken. Er wordt aan hen getrokken door opleiders, begeleiders, financiers, huisartsen, andere onderzoekers, patiënten, partners en kinderen. Zorgen over de voortgang van het onderzoek gaan onvermijdelijk een beetje mee naar de spreekkamer, terwijl het onzekere gevoel dat iedere aankomende huisarts kent naebt in het contact met weer die andere huisartsen die toevallig aan zijn onderzoek deelnemen. Jezelf staande houden in dit krachtenveld is een kunst op zich, die, analoog aan de onbedoeld nogal Japans klinkende afkorting van hun functie, lijkt op het voor de eerste keer eten met stokjes. Echter, het construct AlOTHO is nog jong en bezig om een paar kinderziektes te boven te komen. De bellangrijkste en op het moment meest bedreigende zijn de vraagstukken rond de aanstellingsprocedure en rechtspositie van (beoogde) AlOTHO's, alsmede de nog moeizame afstemming tussen het onderzoeksdeel en huisartsopleiding van het traject. Stroomlijning op deze punten is dringend gewenst. $O p$ locaal en landelijk niveau is over deze onderwerpen overleg gaande. 
Onderzoekers, AlOTHO of niet, komen niet zomaar uit de lucht vallen en het spreekwoord 'Wat de boer niet kent .... gaat ook hier op. Waar kinderen moeten leren om spruitjes te eten, ondergaan veel geneeskunde-studenten een vergelijkbare ervaring wanneer zij voor het eerst kennis maken met wetenschappelijk onderzoek. Immers, de studie geneeskunde mag wetenschappelijk heten maar heeft in essentie veel weg van een hogere beroepsopleiding. Zo is er slechts éen eindprodukt, namelijk de basisarts, en de weg ernaar toe is feitelijk van de eerste tot en met de laatste dag beschreven, inclusief een periode van (minimaal) drie maanden onderzoek doen. Het resultaat is de paradoxale situatie dat we in ons land goede artsen opleiden, die tegelijkertijd de evidence van hun handelen ternauwernood op hun waarde kunnen schatten. Zo is een kritische evaluatie van de eigen vakliteratuur voor veel huisartsen helaas nog steeds geen gemeengoed. Dat daarmee de weg open ligt naar allerlei, meestal goed bedoelde beïnloeding van buitenaf laat zich raden. Het is aan de beroepsgroep zelf, maar ook aan de faculteiten der geneeskunde, om aan deze ongewenste situatie een einde te maken. Zo zou het mooi zijn als over vijf jaar onze cursus "Kritisch lezen voor huisartsen' van onze (oorspronkelijk Vllaams-Maastrichtse) Huisarts-onderzoekers Opleiding overbodig is geworden.

Even terugdenkend aan de spruitjes, ligt het voor de hand om al in een vroeg stadium wan de studie geneeskunde te beginnen met het leren eten van het gezonde voedsel dat wetenschap heet. Het is in dat verband een groot goed dat de Maastrichtse faculteit der geneeskunde kort geleden van start ging met het Onderzoeks Traject Geneeskunde (OTG), zijnde een programma waarin studenten op vrijwillige basis, twee jaar lang, gedurende een dag per week, onder deskundige begeleiding onderzoek doen. Maar we zijn er bij lange na nog niet. De klacht van veel studenten dat onderzoek niet meer dan theoretische ballast is, is helaas vaak terecht. Zo is de aansluiting aan de dagelijkse praktijk van huisarts en ziekenhuisspecialist regellmatig ver te zoeken.

Artsen en studenten geneeskunde dienen het verband te ervaren tussen de praktijk van alledag en haar wetenschappelijke achtergrond, alvorens enthousilast te worden voor het doen van wetenschappelijk onderzoek. Het is dan ook zaak om patiëntenzorg, onderzoek en onderwijs zoveel mogelijk een drieëenheid te laten zijn. Het AlOTHO-traject is daarvan een actueel voorbeeld binnen de huisartsopleiding. Het bij elkaar brengen wan het OnderzoeksTraject Geneeskunde en het Praktisch Medisch Onderwijs Huisartsgeneeskunde is wat mij betreft een volgende stap (ik kom daar straks nog op terug). En daar hoeft het niet bij te blijven. In onderwijsgroepen is de systematische aanpak van een klinisch probleem een goede gelegenheid om theoretische aspecten van de dagelijkse praktijk aan de orde te stellen. Opnieuw gaat dan de praktijk van alledag (in dit geval bestaande uit een gevalsbeschrijving op papier) gepaard met wetenschappelijke verdieping. 
Onderwijs en onderzoek gaan zodoende hand in hand, en de student is begonnen met wetenschappelijk denken nog voordat hij het zelf in de gaten heeft. zo krijgt bijwoorbeeld de diagnostische gevoeligheid (sensitiviteit) van de klacht 'hoesten' voor longkanker pas voluit betekenis zodra een student met eigen ogen gezien heeft hoe gemakkelijk een zeer ernstige ziekte in de praktijk kan worden gemist. Een voorbeeld is de zichtbare schok die door een van de in deze zaal aanwezige jongerejaars studenten ging toen hij kort geleden bij een van mijn patiënten mocht vaststellen dat een paar weken bestaande hoest bij een zich overigens uitstekend voelend wat oudere man bleek te berusten op een ver. gevorderd stadium van longkanker. Dezelfde student zal zich dan als co-assistent en daarna als praktizerend (huis)arts wellicht afvragen welke andere gegevens hem nog beter in staat stellen om de diagnose niet te missen. Met andere woorden, de begrippen sensitiviteit, specificiteit en voorspellende waarde (nogal eens samengevat met de woorden "de beruchte viervelden tabel') veroorzaken bij hem geen buikpijn meer, maar worden gebruikt om de valkliteratuur er nog eens op na te slaan, meningen van diverse auteurs met elkaar te vergelijken, zelf een eerste conclusie te trekken en deze toe te passen in de eigen spreekkamer. Dit toepassen leidt overigens vaak tot nieuwe vragen die op hun beurt de moeite van het onderzoeken waard kunnen zijn. De basis voor een kleinschalig onderzoek in de eigen (huis)artspraktijk is op dat moment gelegd.

Integratie van praktijk, onderzoek en onderwijs maakt het mogelijk om binnen onderzoekslijnen een soort loopbaanontwikkeling en inhoudelijke en structurele hiërarchie tot stand te brengen. Zo is de huisarts-onderzoeker van ons eerste osteoporose-project inmiddels begeleider van de student-onderzoeker die is aangesteld op de vervolgstudie en aanvankelijk met een wetenschapsstage binnen het project van start was gegaan. Inmiddels wordt deze student-onderzoeker bijgestaan door een student-assistent, een huisarts-in-opleiding, twee tweedejaars studenten die het OnderzoeksTraject Geneeskunde volgen, en naar verwachting binnenkort ook nog door een co-assistent. leder van hen concentreert zich op een of meerdere deelvraagstellingen en zal hierover rapporteren.

Een ander voorbeeld is het project 'lage luchtweginfecties'. De onderzoeker, eên van de AlOTHO's, ging van start met een wetenschapsstage en wordt op dit moment bijgestaan door een student-assistent en twee huisartsen-in-opleiding. Waar de laatste twee hun wetenschappelijke vorming krijgen in het project, is de onderzoeker zelf consulent voor weer andere huisartsen-in-opleiding. Hiërarchie en wisselwerking gaan in hier hand in hand, en verdere ontwikkeling is zeker mogelijk. Zo kan ik mij voorstellen dat met de differentiatie en de er aan. komende flexibilisering van de huisartsopleiding, huisartsen-in-opleiding de kans krijgen om zich meer dan gemiddeld te verdiepen in wetenschappelijk onderzoek en hun collega's helpen met het eten van de wetenschappelijke spruitjes. 
Warar de osteoporose-onderzoeker in korte tijd doorgroeide van student naar onderzoeker, gingen diverse anderen hem op vergelijkbare wijze voor. Zo hebben 8 van de 1o (beoogde) AIOTHO's een voorgeschiedenis van een of meerdere wetenschapsstages of ander keuze-onderwijs bij de vakgroep Huisartsgeneeskunde. De kwalificatie 'eigen kweek" is dan ook vaak wan toepassing, en dit onderstreept de groeiende interactie tussen onderwijs en onderzoek.

Maar niet alleen het reguliere onderwijs, ook de huisartspraktijk zelf is een goede kweekvijver voor onderzoekers. Heel expliciet geldt dit voor de academische huisartspraktijken en de praktijken die deelnemen aan het RegistratieNet Huisartspraktijken van de Universiteit Maastricht. In dit geautomatiseerde netwerk worden sedert 1988 gegevens omtrent ziekte en gezond heid van ongeveer 100.000 mensen, ingeschreven bij 45 huisartsen, dagelijks bijgehouden. Het Netwerk geeft niet alleen inzicht in hoe gezondheid en ziekte zich ontwikkelen, ook is het een ideaal steekproefbestand voor wetenschappelijk onderzoek. Patiëntenzorg en onderzoek gaan in het Netwerk hand in hand. Inmiddels zijn vanuit en op basis van het Netwerk all meer dan to huisartsgeneeskundige promoties voortgekomen, en er komen er nog diverse aan.

In de academische en Netwerkpraktijken, waarvan de huisartsen een formele binding aangaan met de faculteit der geneeskunde, worden niet alleen veel gegevens verzameld op verzoek van andere onderzoekers, in toenemende mate zijn ook de onderzoekers zelf afkomstig uit deze praktijken. Zo zijn de laatste jaren in Maastricht een reeks academische huisartsen gepromoveerd en bestond er zonder uitzondering veel belangstelling voor hun werk, getuige een reeks publikaties in hoog aangeschreven (inter)nationale vakbladen (zoals die over de resultaten van het influenza-onderzoek) en in de landelijke pers. Daarnaast is hun werk niet alleen terug te vinden in Standaarden van het Nederlands Huisartsen Genootschap, maar bijvoorbeeld ook in rapporten van de Gezondheidsraad. Desalniettemin worden de academische en Netwerkpraktijken aanhoudend budgettair bedreigd. Een structureel verankerd financieel fundament is dringend gewenst en zou even vanzelfsprekend moeten zijn als de systematische steun die academische ziekenhuizen ontvangen. Het fundament is niet alleen nodig om succesvol onderzoek te kunnen blijven genereren en doen, ook stelt het ons in staat om AIOTHO's het noodzakelijke beroepsperspectief te bieden.

In de academische huisartspraktijken bestaat bovendien de mogelijkheid om praktijk, onderzoek en onderwijs optimaal te integreren. In het Maastrichtse curriculum brengt iedere student geneeskunde gedurende twee jaar elke zes weken éen dag door in een huisartspraktijk (het zogenaamde 'Adoptieprogramma'), alwaar zij regelmatig aantrekkelijk uitziende wetenschappelijke spruitjes zien langskomen. Het ligt voor de hand om ze te proeven, daarbij deskundig begeleid 
door de betreffende huisarts-opleider die wellicht ook zelf bezig is met het doen wan een onderzoek en blij is met enige uitbreiding van zijn projectgroep. Uit de patiënten die deze studenten zelf zien kunnen zij een selectie maken van diegenen die in aanmerking komen voor hun eigen (deel)onderzoek. Omdat de student bovendien twee jaar lang in de dezelfde praktijk terugkomt en omdat juist de huisarts regelmatig te maken heeft met patiënten met chronische aandoeningen of terugkerende problemen, ontstaat de mogelijkheid om patiènten lang te vervolgen. De student verwerft bijvoorbeeld inzicht in de mogelijkheid dat een patiënte met botontkalking binnen twee jaar lets breekt, de redenen waarom patiënten na enige tijd hun medicijnen niet meer innemen en de relatie tussen telkens terugkerende hoest en de aanwezigheid van een allergie.

Samenvattend is het mijn vurige wens dat het patiënt-gebaseerd leren waar Crebolder in 1987 in zijn rede een lans voor brak, met toevoeging van het onderdeel onderzoek doorgroeit van een hechte tweeëenheid naar een vruchtbare drieëenheid.

Dames en heren, bij een gelegenheid als deze is het ook goed om even afstand te nemen van hetgeen was en gaat komen. Zoals sommigen van u weten is afstand nemen ook letterlijk een van mijn geliefde bezigheden. Het heeft me in staat gesteld om het werk hier bij tijd en wijle te relativeren en tegelijkertijd ideeën en energie op te doen voor een vervolg. Zo heb ik in gedachten het werk van één van mijn Filippijnse callega's, in een uitloper van de grote afvalberg die hoort bij de hoofdstad Manila, nogal cynisch de tweede 'S mokey Mountain' genoemd. Gezond zijn staat hier synoniem met overleven, hetgeen op het eerste gezicht iets anders is dan het in ons land uitpluizen van onbegrepen klachten. Maar zo heel groot is dat verschil ook weer niet. Zo geldt voor de bewoners van Smokey Mountain, maar bijvoorbeeld ook voor de jonge mijnwerker in Brazilië, dat de klacht moeheid in combinatie met hoesten maar in beperkte mate voorspellend is voor de aanwezigheid van tuberculose, terwijl u voor de situatie in Nederland bij deze twee klachten het woord tuberculose gevoeglijk kunt vervangen door longontsteking of asthma.

In een andere gemeenschap, niet ver van Smokey Mountain, wordt onderzocht in welke mate het efficiënt is om de noodzakelijke medicijnen tegen tuberculose onder toezicht te laten innemen. In ons project "lage luchtweginfecties" wordt de inname van antibiotica weliswaar niet geobserveerd maar wel gemeten met slimme elektronische apparatuur. De achtergrond is echter identiek: in beide landen zijn patiënten all snel geneigd om hun medicijnen te laten staan zodra ze zich weer wat beter voelen.

Het is daarnaast leerzaam om te zien hoe de Filippijnse studenten met een groot gebrek aan middelen er toch in slagen om onderzoek op te zetten en uit te voeren. Maar ook een stuk dichter bij huis zijn de omstandigheden voor het 
doen van huisartsgeneeskundig relevant onderzoek niet bepaald gunstig. Het stukgeschoten hoofdkwartier van de Securitate (in Boekarest) is niet alleen een symbool van de aftocht van het communisme, evenzeer is het (onbedoeld) illustratief voor de staat waarin Roemenie zich no jaar na de revolutie nog steeds bevindt. Hast tegen de stroom in slagen de deelnemers a an onze aldaar lopende Huisarts onderzoekers Opleiding er in om zelf relevant (kleinschalig) onderzoek op te zetten en uit te voeren, vaak met als enig instrument een stethoscoop (en soms een weegschaal of een bloeddrukmeter), maar met een onvoorstelbaar groot enthousiasme en doorzettingsvermogen, en voor een salaris dat gemiddeld niet meer dan $10 \%$ bedraagt van dat van onze onderzoekers.

Het zijn juist deze gebieden, ver van huis, waar studenten van onze faculteit een schat aan ervaring kunnen opdoen. De gebieden zijn opgenomen in ons pakket uitwisselingsprogramma's Primary Health Care voor studenten, dat inmiddels in op een na alle werelddelen is gesitueerd. Aan de basis van deze programma's stonden veelal studenten, onder wie (misschien wel niet toevallig) vijf van onze huidige AIOTHO's.

Inmiddels ben ik aan het einde gekomen van mijn vogelvlucht door huisartsgeneeskundig onderzoekland. Ik heb geprobeerd om te schetsen hoe de breedte van het vak huisartsgeneeskunde herkenbaar is in het wetenschappelijk onderzoek dat in deze discipline plaats vindt. Voorts heb ik uitgelegd dat een aantal investeringen nodig zijn om een goede toekomst te kunnen garanderen. Bij dat alles stonden de innige relatie tussen 'evidence' en 'practice', en de opleiding van studenten, huisartsen en onderzoekers centraal en kon ik ter illustratie dankbaar gebruik maken van ervaringen met eigen onderzoek. Vanzelfsprekend heb ik mensen tekort gedaan door niet impliciet naar hen te verwijzen. Bovendien ben ik mij ervan bewust niet volledig te zijn geweest. Graag maak ik dat weer goed bij een volgende gelegenheid, hoewel mijn rede dan waarschijnlijk geen Rede meer mag heten. Het was voor mij een groot plezier om deze tekst op te stellen en een nog groter genoegen om hem hier voor $u$ uit te spreken. Op deze plaats dank ik graag het College van Bestuur en het Faculteits Bestuur van de Faculteit der Geneeskunde van de Universiteit Maastricht voor het in mij gestelde vertrouwen. Tot slot wil ik graag heel kort een paar mensen toespreken, mensen zonder wie bovenstaande niet mogelijk was geweest.

Harry Crebolder, je bent niet alleen reeds lange tijd een prima voorzitter van onze vakgroep, maar voor mij ook anderszins een groot woorbeeld. In weinigen zie ik dat het combineren van patiëntenzorg, onderzoek en onderwijs zo lang en succesvol is vol te houden.

André Knottnerus, het staat vast dat ik zonder jou hier niet had gestaan. Heel subtiel liet je me tien jaar geleden al zien wat het is orm een echte onderzoeker 
te zijn: wetenschap maakt dorstig en kennis draag je niet alleen figuurlijk maar ook letterlijk overall met je mee. Samen stelden we toen, niet ver van een symbolische plaats in Israël, vast dat je na afloop van een congresreisje vooral niet moet toegeven dat het leuk was. Maar "helaas" praat ik sindsdien steeds vaker mijn mond voorbij.

Tot slot, onderzoek en onderwijs doe je niet alleen. In de bijna $121 / 2$ jaar dat ik nu in Maastricht werkzaam ben, was het telkens weer een groot plezier om

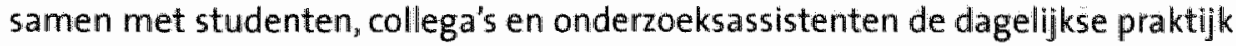
te verkennen, en onderzoek op te zetten, uit te voeren en te publiceren. Het letterlijk voor de eerste keer aanraken van een 'echte' patiënt is voor iedere student een kleine life event, en het begeleiden van het proces wat daarop volgt zal mij nooit gaan vervelen. Waar het daarnaast soms mijn initiatief was dat onderzoekers definitief op gang bracht, was het omgekeerd hun zichtbaar toenemend enthousiasme dat mij telkens weer deed uitkijken naar een volgend project. Heel graag ga ik met jullie (waarvan een bellangrijk aantal hier aanwezig) en met jullie opvolgers nog heel lang door.

Ik heb gezegd. 
Baker $R$, Thompson J. Innovation in general practice: is the gap between training and non-training practices getting wider? Br J Gen Pract 1995:45:297-300

Boot RJM, Op't Root JMH, Dinant GJ. Keuze-co-assistentschap huisartsgeneeskunde in Canada; een ander referentiekader als verborgen schat. Med Contact $1996 ; 51: 1117-18$

Busari OJ, Peeters $G$. Vissers F. General practice in Maastricht. The community, the culture, and the delivery of health care services. Med Contact 1997;5:2:1050-52

Crebolder HFIM. Te leer in de eerste lijn. Huisarts Wet 1987;30:308-13

Crebolder HFIM, Metsemakers JFM, Op't Root $I M H$, Barthelomeus P, Bouhuijs $P$, Boshuizen HPA. Patiëntgebonden onderwijs in de huisartspraktijk binnen de artsopleiding; het programma van de Rijksuniversiteit Limburg. Ned Tijdschr Geneeskd 1996;140:1320-23

Cursiefen $C$, Beer $M$, Altunbas A. Should all medical students do research during their studies? Med Education 1995;29:254

Dinant G. Bloedonderzoek in de huisartspraktijk. In: Van E5 JC et al. Het Medisch Jaar 1989: 39-46. Utrecht/Antwerpen: Bohn, Scheltema \& Holkema, 1989

Dinant GJ, De Kock CA, Van Wersch JWJ. Diagnostic value of C-reactive protein measurement does not justify replacement of the erythrocyte sedimentation rate in daily general practice. Eu J Clin Invest 1995;25:353-59

Dinant GJ, De Maesseneer J, Derese A. How many ROC curves fit into one general practitioner? Huisarts Wet 1993;36:58-61

Dinant GJ, Knottnerus JA, Van Wersch JWJ. Discriminating ability of the erythrocyte sedimentation rate: a prospective study in general practice. Br J Gen Pract $1991 ; 41: 365-70$

Dinant GJ, Van Wijk MAM, Janssens HJEM, Somford RG, De Jager Cl, Beusmans GHMI, et al. NHG-Standaard Bloedonderzoek. Huisarts Wet 1994:37:202-11

Doom B, Kocken RJ, Crebolder HFJM, Dinant GJ, Knottnerus IA. Netwerk van academische huisartsenpraktijken. Med Contact 1998;53:1604-6 
Govaert ThME, Dinant GJ Aretz K, Knottnerus JA. The predicitive value of influenza symptomatology in elderly people. Fam Practice 1998;15:16-22

Govaert ThME, Knottnerus IA, Dinant GJ, Sprenger MW, Masurel N. De duur van influenza en influenza-achtige ziekten bij ouderen. Huisarts Wet 1994:37:234-38

Govaert ThME, Thijs CTMCN, Masurel $N_{n}$ sprenger MWW Dinant GJ, Knottnerus JA. The efficacy of influenza vaccination in elderly individuals. JAMA 1994;272:1661-65

Grol $R$, Wensing $M$, Jacobs A, Baker $R$. Quality assurance in general practice; the state of the art in Europe. Utrecht: Nederlands Huisartsen Genootschap, 1993

Health Council of the Netherlands: Committee on Osteoporosis. Prevention of osteoporosis-related fractures. Rijswijk: Health Council of the Netherlands, 1998

Knottnerus JA. Dialectiek van het onderzoek in de huisartsgeneeskunde. Inaugurele rede. Maastricht, 1988

Knottnerus JA. Diagnostic prediction rules: principles, requirements and pitfalls. Med Dec Making 1995;22:341-63

Knottnerus JA. Research in general practice. Lancet 1996;347:1236-38

Knottnerus JA, Dinant $G J$. Medicine-based evidence, a prerequisite for evidencebased medicine. Br Med J 1997;315:1109-10

Kooij LR, Van Ree JW, Knottnerus JA. Opleiding tot huisarts én onderzoeker. Med Contact 1998;53:1196-98

Lamberts $H$, Knottnerus $J A$, Hofmans $S B$, Klaassen $A$. General practice research in Dutch academia. Amsterdam: Royal Netherlands Academy of Arts and Sciences, 1994

Majoor $G D_{n}$ Willemstein SC. Internationalisering van het medisch onderwijs. Ned Tijdschr Geneeskd 1996;140:100-102

Metsemakers JFM, Höppener P, Knottnerus $J_{A}$, Kocken RJ, Limonard CBG.

Computerized health information in the Netherlands: a registration network of family practices. Br J Gen Pract 1992;42:102-6

Muris JWM, Starmans R, Fijten CH, Crebolder HFM, Schouten HJA, Knottnerus JA. Non-acute abdominal complaints in general practice: diagnostic value of signs and symptoms. Br J Gen Pract 1995;45:313-16 
Osteoporosis Committee of the Netherlands Health Council. Osteoporosis: report of the Netherlands Health Council. Ned Tijdschr Geneeskd 1998;142:2502-05

Schadé E, Sminia TD. Eindtermen voor de universitaire artsopleiding: "Raamplan 1994 artsopleiding'. Ned Tijdschr Geneeskd 1995;139:30-34

Schayck CP. De zin en onzin van preventie in de huisartspraktijk. Inaugurele rede. Maastricht, 1998

Stoffers HEJH, Kaiser V, Kester ADM, Rinkens PELM, Knottnerus JA. Diagnostic value of signs and symptoms associated with peripheral arterial occlusive disease seen in general practice: a multivariate approach. Med Dec Making 1997;17:61-70

Van Buchem L, Peeters M, Beaumont J, Knottnerus JA. Acute maxillary sinusitis in general practice: the relation between clinical picture and objective findings. Eu J Gen Pract 1995; 1:155-60

Van der Voort DJM, Brandon S, Dinant GJ, Van Wersch JWJ. Screening for osteoporosis using easily obtailnable bilometrical data: diagnostic accuracy of measured, self-reported and recalled $\mathrm{BMI}_{\mathrm{s}}$ and related costs of bone mineral density measurement. Submitted.

Van der Weijden T, IJzermans CJ, Dinant GJ, Van Duijn NP, De Vet HCW, Buntinx F. Identifying relevant diagnostic studies in medicine. Fam Practice 1997;14:204-208

Vierhout ME. Wetenschappelijk onderzoek in de perifere klinische praktijk - Vooren nadelen. Med Contact 1996;51:1277-79

Vierhout WPM, Knottnerus JA, Van Ooij A, Crebolder HFM, Wesselingh-Megens AMK, Beusmans GHMI. Effectiveness of joint consultation sessions of general practitioners and orthopedic surgeons for locomotor-system disorders. Lancet $1995: 346: 990-94$

Winkens RAG, Pop P, Bugter-Maessen AMA, Grol RPTM, Kester ADM, Beusmans GHMI, Knottnerus JA. Randomised controlled trial of routine individual feedback to improve rationality and reduce numbers of test requests. Lancet $1995: 345: 498-502$

Wolf $R$, De Wit MCY, Van Ark JH, Henning RH, Navis GJ. Studentencongres geneeskunde: lakmoesproef voor kwaliteit wetenschappelijk onderwijs. Med Contact 1997:52:1043-44 